\title{
Expression of components of the IGF signalling system in childhood acute lymphoblastic leukaemia
}

\author{
P Vorwerk, H Wex, B Hohmann, K Mohnike, U Schmidt, U Mittler
}

J Clin Pathol: Mol Pathol 2002;55:40-45

\begin{abstract}
Background: Alterations in the insulin-like growth factor (IGF) system have been reported for different tumours. They are of particular interest in the search for new prognostic and therapeutic approaches in cancer. In childhood acute lymphoblastic leukaemia (ALL) the amount of "fumour mass" at diagnosis can exceed $1 \mathrm{~kg}$. To understand the endocrine, paracrine, and autocrine potential of the malignant transformed progenitor cells, the ability of these cells to express components of the IGF system needs to be investigated.

Aim: To characterise the expression pattern of genes of the IGF system in malignant lymphoblasts of children suffering from AlL.

Methods: Reverse transcription polymerase chain reaction of Ficoll separated mononuclear cells from 142 children with ALL, 127 cord blood samples, and 55 blood samples of age matched controls were studied.

Results: The expression of IGF-I, IGF-II, IGF binding protein 5 (IGFBP-5), and CTGF (IGFBP-rP2) was seen in a higher proportion of mononuclear cells of patients with ALL than in controls. Patients with ALL who were in continuous remission had a lower percentage of IGFBP-2 and IGFBP-3 expressing mononuclear cells at diagnosis than did those who developed a relapse. Only malignant lymphoblasts of $B$ cell origin showed expression of CTGF (IGFBP-rP2). Malignant lymphoblasts of T cell origin more often expressed IGFBP-2 and IGFBP-5, whereas IGF-II and IGFBP-3 expression was seen more often in lymphoblasts of B cell origin.

Conclusions: Malignant lymphoblasts of patients with ALL express components of the IGF system and therefore promote their own growth in an autocrine, paracrine, or endocrine manner. Whether these components will be useful as prognostic factors in the stratification of ALL treatment in children needs to be evaluated.
\end{abstract}

See end of article for authors' affiliations ..................

Correspondence to: Dr P Vorwerk,

Otto-von-Guericke-University, Department of Paediatric Oncology,

Emanuel-Larisch-Weg 17-19, D-39112

Magdéburg, Germany;

Peter.Vorwerk@

medizin.uni-magdeburg.de

Accepted for publication 21 June 2001

S ome of the first evidence indicating that local autocrine or paracrine production of growth factors might be important during the development of cancer comes from the observation that transformed or tumour derived cell lines require less serum for proliferation in vitro than their normal counterparts. ${ }^{1}$ From these early reports emerged the concept of de novo synthesis of polypeptide growth factors by the tumour cells themselves. Among the cytokines that are involved in growth regulation, differentiation, and cell metabolism, the members of the insulin-like growth factor (IGF) signalling system have been shown to be potentially important in most cell types. ${ }^{2}$ The IGF system is a complex network, consisting of the two IGF peptides (IGF-I and IGF-II), two IGF receptors, six well characterised IGF binding proteins (IGFBPs), at least six IGFBP related proteins (IGFBP-rPs), IGFBP and IGFBP-rP cell surface receptor proteins, in addition to IGFBP and IGFBP-rP proteases.

IGF-I and IGF-II are members of the family of insulinrelated peptides, diverged from a common ancestor through evolution. Circulating IGF-I is growth hormone dependent, produced by the liver and extrahepatic tissues. ${ }^{4}$ Therefore, in addition to its endocrine function autocrine/paracrine regulation has been suggested. ${ }^{5}$ IGF-I stimulates DNA synthesis as a progression factor in the cell cycle. ${ }^{6}$ In addition, it has the ability to promote the differentiation of mesenchymal cells and has acute insulin-like metabolic effects. ${ }^{4}$ In contrast, IGF-II is highly expressed during fetal development and there are no pronounced changes in IGF-II values during puberty. IGF-II values in adults are about four times higher than those of IGF-I.

The biological activity of the IGF signalling system is mediated by specific membrane associated glycoprotein receptors: the type 1 and 2 IGF receptors, the insulin receptor, and the chimaeric insulin-IGF-I receptor. The type 1 IGF receptor is closely related to the insulin receptor. The type 2 IGF receptor is identical to the mannose-6-phosphate receptor, ${ }^{7}$ which has a dual function in the transport of lysosomal enzymes from the Golgi apparatus to the endosomes and clearance of IGF-II from the circulation.

High affinity IGFBPs regulate IGF clearance. They prolong the half-life of the IGFs from a few minutes up to 15 hours, protect against the acute insulin-like effects of IGFs, and act as transport proteins across the capillary barrier. They both enhance or inhibit the presentation of IGFs to their receptors and have IGF independent actions. ${ }^{3}$ IGFBP-3 is the major binding protein in serum and, together with the acid labile subunit (ALS), keeps most of the IGFs trapped in a $150 \mathrm{kDa}$ ternary complex.

Recently, a group of cystine rich proteins with striking structural similarities to the IGFBPs were identified. ${ }^{89}$ These proteins belong to the CCN family of matrix associated proteins with diverse signalling functions. ${ }^{10}{ }^{11}$ They contain the same N-terminal GCGCCxxC motif as the IGFBPs and show reduced, but demonstrable, affinities for IGFs. ${ }^{8}{ }^{12}$ The IGFBP superfamily comprises the high affinity IGF binders (IGFBPs) and low affinity binders (IGFBP-rPs). Mac25 (IGFBP-rP1),

Abbreviations: ALL, acute lymphoblastic leukaemia; ALS, acid labile subunit; B-ALL, B cell ALL; BFM, Berlin-Frankfurt-Münster; IGF, insulin-like growth factor; IGFBP, IGF binding protein; IGFBP-rP, IGFBP related protein; RT-PCR, reverse transcription polymerase chain reaction; T-ALL, T cell ALL 


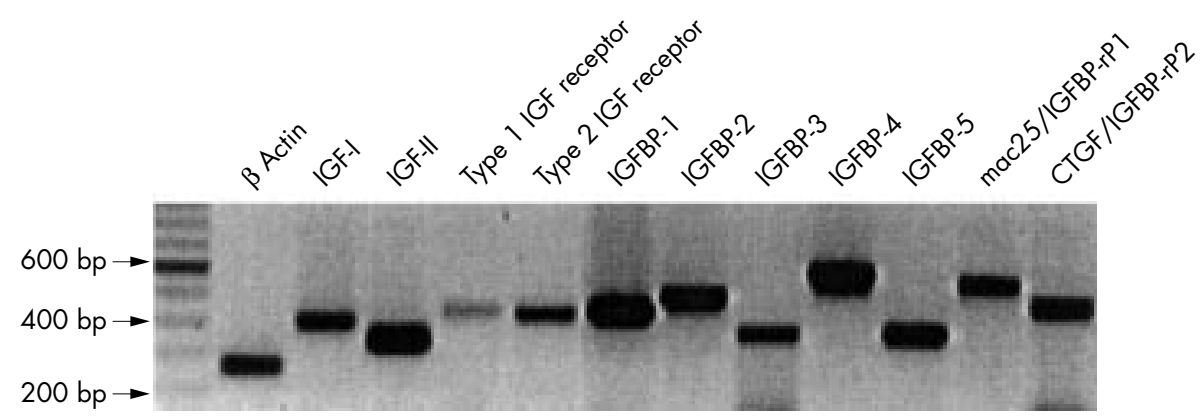

Figure 1 Reverse transcription polymerase chain reaction (RT-PCR) results from control RNA (human placenta and liver) using standard protocols and appropriate sets of primers. All PCR products are between 200 and $600 \mathrm{bp}$. IGF, insulin-like growth factor; IGFBP, IGF binding protein; IGFBP-rP, IGFBP related protein.

CTGF (IGFBP-rP2), and CYR61 (IGFBP-rP3), which are homologous to the IGFBPs only in the N-terminal part of the molecule, bind IGFs, although with at least 1000 times lower affinity than IGFBPs. It has been suggested that the IGFBP superfamily is derived from an ancestral protein that was crucially important in growth regulation and capable of binding insulin-like peptides. During evolution some members evolved into high affinity binders and others into low affinity binders, conferring on the IGFBP superfamily the ability to influence cell growth by IGF dependent and IGF independent actions.' It is noteworthy that some of the IGFBP-rPs have been previously identified as growth factors. ${ }^{\text {' }}$

The biological roles of the IGFBPs involve more than the transport of IGF peptides in biological fluids. A direct association with membrane proteins has been demonstrated for IGFBP-2, IGFBP-3, and IGFBP-5, ${ }^{13}{ }^{14}$ in addition to CTGF (IGFBP-rP2). ${ }^{15}$ IGFBP proteases are another integral component of the IGF system. ${ }^{16}$ Limited proteolysis of IGFBPs controls the biological actions of $\mathrm{IGF}^{17}$ and is responsible for the IGF independent functions of IGFBP fragments. ${ }^{18-20}$

Alterations in the IGF system have been reported for many different tumours, including acute lymphoblastic leukaemia (ALL). ${ }^{21-24}$ ALL is considered to be a heterogeneous entity characterised by immunophenotypic, genetic, and clinical findings. Changes in the IGF system are of particular interest in view of the search for prognostic factors in leukaemia to help determine the antileukaemic treatment, whether to prevent overtreatment in those patients with a good prognosis or to justify experimental therapeutic approaches in others. The characterisation of the IGF system in childhood ALL was initiated by our group as part of the cooperative study protocol ALL-BFM 95.

\section{MATERIALS AND METHODS \\ Patients}

One hundred and forty two children with ALL from 22 different trial centres of the Berlin-Frankfurt-Münster (BFM) study group were studied prospectively from 1988, before and during treatment. A continuous complete remission of more than two years was seen in 118 patients, whereas 24 developed a haematological relapse within two years. One hundred and nine of the patients $(81 \%)$ suffered from B-precursor cell ALL (B-ALL, four; pre-B-ALL, 20; common ALL, 84; pro-B-ALL, one), whereas $26(19 \%)$ suffered from T cell ALL (mature T-ALL, six; intermediate T-ALL, 17; pre-T-ALL, three). The immunophenotype was not determined accurately in seven patients.

All patients were investigated at diagnosis and 41 were also investigated when in complete clinical remission (day 33 of treatment). Furthermore, 55 blood samples of age matched healthy children and 127 cord blood samples from healthy newborns were studied as controls. Informed consent was obtained from the participating patients or their parents in adherence with the guidelines of the ethics committee.

\section{Methods}

Mononuclear cells were separated using gradient centrifugation with Ficoll-Paque (Pharmacia, Uppsala, Sweden). At the time of diagnosis, the tumour clones generally represented $40-99 \%$ of the mononuclear cell fraction. Total RNA was extracted using the QIAshredder ${ }^{\circledR}$, RNeasy ${ }^{\oplus}$, and RNase free DNase set (Qiagen, Hilden, Germany), according to the manufacturer's protocol. The RNA was stored at $-80^{\circ} \mathrm{C}$ until use and $2 \mu \mathrm{g}$ samples of total RNA were reverse transcribed into cDNA by Omniscript reverse transcriptase (Qiagen), as recommended by the manufacturer. Aliquots $(0.5 \mu \mathrm{l})$ of cDNA were used for enzymatic amplification in $50 \mu \mathrm{l}$ reactions containing $10 \times$ reaction buffer mixture, 1 unit Taq polymerase (Qiagen), and $0.2 \mathrm{pmol}$ of appropriate gene specific primers in a Hybaid gene thermocycler (P Vorwerk, et al. Presented at the third international symposium on insulin-like growth factor binding proteins, Tuebingen, Eberhard Karl Universität, 1995). ${ }^{25}$ The expression of the following genes was studied in malignant lymphoblasts by reverse transcription polymerase chain reaction (RT-PCR): $\beta$ actin, IGF-I, IGF-II, the type 1 IGF receptor, the type 2 IGF receptor, IGFBPs 1-5, Mac25 (IGFBP-rP1), and CTGF (IGFBP-rP2) (fig 1). Each cDNA was first checked for integrity and possible contamination with genomic DNA. In general, $\beta$ actin negative cDNA samples were excluded from the analyses. The following primers and PCR conditions were used (all genes are given with database accession number and primer localisation):

- $\beta$ Actin (M10277): 5' primer: nucleotides (nt) 1131-1148, 3' primer: nt $2888-2869$ ( $95^{\circ}$ for three minutes, then 35 cycles at $95^{\circ} \mathrm{C}$ for one minute, $55^{\circ} \mathrm{C}$ for one minute, and $72^{\circ} \mathrm{C}$ for one minute, followed by $72^{\circ} \mathrm{C}$ for 10 minutes).

- IGF-I (X00173): 5’ primer: nt 16-39, 3’ primer: nt 413-391 (cycling conditions as for $\beta$ actin).

- IGF-II (NM_000612): 5' primer: nt 537-556, 3' primer: nt $868-849\left(95^{\circ} \mathrm{C}\right.$ for three minutes, then 35 cycles at $95^{\circ} \mathrm{C}$ for one minute, $62^{\circ} \mathrm{C}$ for one minute, and $72^{\circ} \mathrm{C}$ for one minute, followed by $72^{\circ} \mathrm{C}$ for 10 minutes).

- Type 1 IGF receptor (X04434): 5' primer: nt 2464-2483, 3' primer: nt 2909-2891 (cycling conditions as for $\beta$ actin).

- Type 2 IGF receptor (Y00285): 5' primer: nt 345-364, 3' primer: nt $766-745\left(95^{\circ} \mathrm{C}\right.$ for three minutes, then 35 cycles at $95^{\circ} \mathrm{C}$ for one minute, $60^{\circ} \mathrm{C}$ for one minute, and $72^{\circ} \mathrm{C}$ for one minute, followed by $72^{\circ} \mathrm{C}$ for 10 minutes).

- IGFBP-1 (M20841): 5' primer: nt 396-415, 3’ primer: nt 841-812 (cycling conditions as for type 2 IGF receptor).

- IGFBP-2 (M35410): 5' primer: nt 506-525, 3' primer: nt 1002-983 (cycling conditions as for IGF-II).

- IGFBP-3 (X64875): 5' primer: nt 466-485, 3' primer: nt 892-873 (cycling conditions as for IGF-II).

- IGFBP-4 (M62403): 5' primer: nt 252-271, 3' primer: nt 844-821 (cycling conditions as for IGF-II). 
Table 1 Expression of genes of the IGF system in mononuclear cells from patients with acute lymphoblastic leukaemia (ALL) at diagnosis, healthy age matched controls, and cord blood samples

\begin{tabular}{|c|c|c|c|c|c|}
\hline \multirow{4}{*}{$\frac{\text { Genes }}{\text { IGF-I }}$} & \multicolumn{5}{|c|}{ Patients positive for expression (\%) } \\
\hline & \multirow{3}{*}{$\begin{array}{l}\text { ALL }(N=142) \\
29 \%\end{array}$} & \multicolumn{4}{|c|}{ Controls } \\
\hline & & \multicolumn{2}{|c|}{ Blood $(N=55)$} & \multicolumn{2}{|c|}{ Cord blood $(\mathrm{N}=127)$} \\
\hline & & $7 \%$ & 0.001 * & $4 \%$ & 0.001 * \\
\hline |GF-II & $67 \%$ & $31 \%$ & 0.001 * & $80 \%$ & $0.013^{*}$ \\
\hline IGF-IR & $68 \%$ & $87 \%$ & $0.010 *$ & $39 \%$ & 0.001 * \\
\hline IGF-IIR & $60 \%$ & $63 \%$ & 0.726 & $76 \%$ & $0.050 *$ \\
\hline |GFBP-I & $0 \%$ & ND & & ND & \\
\hline IGFBP-2 & $63 \%$ & $60 \%$ & 0.660 & $5 \%$ & $0.001 *$ \\
\hline IGFBP-3 & $25 \%$ & $35 \%$ & 0.162 & $0 \%$ & $0.001 *$ \\
\hline IGFBP-4 & $42 \%$ & $44 \%$ & 0.860 & $24 \%$ & $0.002 *$ \\
\hline IGFBP-5 & $20 \%$ & $2 \%$ & $0.001 *$ & $0 \%$ & 0.001 * \\
\hline |GFBP-rPI & $17 \%$ & $7 \%$ & 0.089 & $13 \%$ & 0.456 \\
\hline IGFBP-rP2 & $52 \%$ & $0 \%$ & 0.001 * & $0 \%$ & 0.001 * \\
\hline
\end{tabular}

Differences between the control group and the patients with ALL were tested with the $\chi^{2}$ test ${ }^{*} p \leqslant 0.05$.

IGF, insulin-like growth factor; IGFBP, IGF binding protein; IGFBP-rP, IGFBP related protein; IGF-IIR, IGF-II receptor; ND, not determined.

- IGFBP-5 (AF055033): 5’ primer: nt 1199-1218,3' primer: nt 1565-1542 (cycling conditions as for IGF-II).

- IGFBP-rPl (L19182): 5' primer: nt 286-309, 3' primer: nt 836-813 (cycling conditions as for IGF-II).

- IGFBP-rP2 (U14750): 5' primer: nt 371-389, 3' primer: nt 842-824 (cycling conditions as for IGF-II).

\section{Statistical analysis}

The different patient groups were compared with the $\chi^{2}$ test. Logistic regression was used to identify independent parameters that can distinguish between the different sample groups. The 41 patients with ALL studied at diagnosis and remission were compared by the two site McNemar test. All statistical data are explorative analyses and were done using SPSS version 10. Significance was set at $p \leqslant 0.05$.

\section{RESULTS}

Tables $1-4$ show the percentage of patients who expressed the genes of interest in their mononuclear cells. Table l compares samples from patients with ALL at diagnosis with healthy

Table 2 Expression of genes of the IGF system in mononuclear cells from patients with acute lymphoblastic leukaemia (ALL) at diagnosis and at complete clinical remission (day 33 of treatment according BFM study protocol)

\begin{tabular}{llll}
\hline & \multicolumn{2}{l}{ ALL patients positive (\%) } & \\
\cline { 2 - 3 } Genes & $\begin{array}{l}\text { Diagnosis } \\
(\mathrm{N}=41)\end{array}$ & $\begin{array}{l}\text { Remission } \\
(\mathrm{N}=41)\end{array}$ & $\mathrm{p}$ Value \\
\hline IGF-I & $24 \%$ & $39 \%$ & 0.210 \\
IGF-II & $63 \%$ & $78 \%$ & 0.180 \\
IGF-IR & $69 \%$ & $66 \%$ & 1.000 \\
IGF-IIR & $46 \%$ & $49 \%$ & 1.000 \\
IGFBP-1 & $0 \%$ & $0 \%$ & \\
IGFBP-2 & $59 \%$ & $56 \%$ & 1.000 \\
IGFBP-3 & $22 \%$ & $41 \%$ & 0.115 \\
IGFBP-4 & $34 \%$ & $27 \%$ & 0.664 \\
IGFBP-5 & $19 \%$ & $46 \%$ & $0.0211^{*}$ \\
IGFBP-rP1 & $18 \%$ & $10 \%$ & 0.453 \\
IGFBP-rP2 & $49 \%$ & $13 \%$ & $0.003^{*}$ \\
\hline
\end{tabular}

Differences between groups were tested with the McNemar test. ${ }^{*} p \leqslant 0.05$.

BFM, Berlin-Frankfurt-Münster; IGF, insulin-like growth factor; IGFBP IGF binding protein; IGFBP-rP, IGFBP related protein; IGF-IIR, IGF-II receptor. control and cord blood samples. IGF-II was the main IGF expressed in all groups, with a maximum in cord blood samples. However, the percentage of patients expressing IGF-I in their mononuclear cells was significantly higher in patients with ALL. Significant differences were found for the expression of IGF-I, IGF-II, type I IGF receptor, and IGFBP-5. CTGF (IGFBP-rP2) was only expressed in patients with ALL (table 1) and IGFBP-1 was not expressed in patients with ALL (tables $1-4)$.

Logistic regression analysis revealed a combination of the following genes for a significant discrimination between the ALL group and the control groups (in order of importance).

- Patients with ALL versus healthy controls: (1) IGFBP-rP2 (CTGF), (2) IGFBP-5, (3) type I IGF receptor, (4) IGF-II, and (5) IGFBP-3. This model recognised $90.9 \%$ of the samples from patients with ALL and $70.8 \%$ of those from the healthy controls. This model recognised $87.3 \%$ of the samples from the patients with ALL and $96.8 \%$ of the cord blood samples.

Table 3 Expression of genes of the IGF system in mononuclear cells from patients with acute lymphoblastic leukaemia (ALL) at diagnosis

\begin{tabular}{lllll}
\hline & \multicolumn{2}{l}{ ALL patients positive (\%) } & \\
\cline { 2 - 4 } Genes & $\begin{array}{l}\text { Total } \\
(\mathrm{N}=142)\end{array}$ & $\begin{array}{l}\text { No relapse } \\
(\mathrm{N}=118)\end{array}$ & $\begin{array}{l}\text { Relapse } \\
(\mathrm{N}=24)\end{array}$ & p Value \\
\hline IGF-I & $29 \%$ & $29 \%$ & $29 \%$ & 0.972 \\
IGF-II & $67 \%$ & $65 \%$ & $75 \%$ & 0.355 \\
IGF-IR & $68 \%$ & $67 \%$ & $75 \%$ & 0.441 \\
IGF-IIR & $60 \%$ & $60 \%$ & $63 \%$ & 0.820 \\
IGFBP-1 & $0 \%$ & $0 \%$ & $0 \%$ & \\
IGFBP-2 & $63 \%$ & $59 \%$ & $83 \%$ & $0.026^{*}$ \\
IGFBP-3 & $25 \%$ & $21 \%$ & $42 \%$ & $0.041^{*}$ \\
IGFBP-4 & $42 \%$ & $40 \%$ & $54 \%$ & 0.195 \\
IGFBP-5 & $20 \%$ & $18 \%$ & $29 \%$ & 0.240 \\
IGFBP-rP1 & $17 \%$ & $16 \%$ & $24 \%$ & 0.405 \\
IGFBP-rP2 & $52 \%$ & $52 \%$ & $52 \%$ & 0.971 \\
\hline
\end{tabular}

The group of 142 patients was divided into patients continuously in remission (no relapse, 118 patients) and those who relapsed (24 patients).

Differences between the relapse and no relapse groups were tested with the $\chi^{2}$ test.

${ }^{*} p \leqslant 0.05$.

IGF, insulin-like growth factor; IGFBP, IGF binding protein; IGFBP-rP, IGFBP related protein; IGF-IIR, IGF-II receptor. 
Table 4 Expression of genes of the IGF system in mononuclear cells from patients with acute lymphoblastic leukaemia (ALL) at diagnosis

\begin{tabular}{|c|c|c|c|}
\hline \multirow[b]{2}{*}{ Genes } & \multicolumn{2}{|c|}{ ALL patients positive (\%) } & \multirow[b]{2}{*}{ p Value } \\
\hline & $\begin{array}{l}\text { B cell } \\
(N=109)\end{array}$ & $\begin{array}{l}\text { T cell } \\
(\mathrm{N}=26)\end{array}$ & \\
\hline IGF-I & $29 \%$ & $31 \%$ & 0.887 \\
\hline IGF-II & $72 \%$ & $50 \%$ & $0.035^{*}$ \\
\hline IGF-IR & $66 \%$ & $81 \%$ & 0.146 \\
\hline IGF-IIR & $58 \%$ & $65 \%$ & 0.520 \\
\hline IGFBP-1 & $0 \%$ & $0 \%$ & \\
\hline IGFBP-2 & $58 \%$ & $88 \%$ & $0.003^{*}$ \\
\hline IGFBP-3 & $28 \%$ & $15 \%$ & 0.200 \\
\hline IGFBP-4 & $44 \%$ & $38 \%$ & 0.606 \\
\hline IGFBP-5 & $13 \%$ & $44 \%$ & 0.001 * \\
\hline |GFBP-rP| & $16 \%$ & $19 \%$ & 0.770 \\
\hline IGFBP-rP2 & $66 \%$ & $0 \%$ & 0.001 * \\
\hline
\end{tabular}

The patients with ALL were divided in patients with B cell immunophenotype (109 patients) and T cell immunophenotype (26 patients). Differences between both groups were tested with the $\chi^{2}$ test.

${ }^{*} \mathrm{p} \leqslant 0.05$.

IGF, insulin-like growth factor; IGFBP, IGF binding protein; IGFBP-rP, IGFBP related protein; IGF-IIR, IGF-II receptor.

- Samples from patients with ALL versus cord blood samples: (1) IGFBP-2, (2) IGFBP-rP2 (CTGF), (3) the type 2 IGF receptor, (4) IGF-I, and (5) IGF-II.

The percentage of patients with ALL expressing the genes of interest in their mononuclear cell fraction at diagnosis was compared with that seen for patients with ALL in clinical remission (table 2). After the initial treatment with prednisone, vincristin, daunorubicin, and asparaginase, according to the BFM protocol, a higher percentage of patients expressed IGF-I, IGF-II, IGFBP-3, and IGFBP-5 in their mononuclear cell fraction, whereas the expression of CTGF (IGFBP-rP2) decreased from $52 \%$ to $16 \%$ (table 2). Significant changes were found in IGFBP-5 and CTGF (IGFBP-rP2) only.

To date, 24 of the 142 patients with ALL studied have developed a relapse. Table 3 shows the comparison between the patients who developed a relapse (24 patients) and those who are still in complete haematological remission (118 patients). Significant differences were found in IGFBP-2 (83\% relapse $v$ $59 \%$ remission) and IGFBP-3 (42\% relapse $v 21 \%$ remission) (table 3). However, in general the percentage of patients expressing IGFBPs in their mononuclear cell fraction at diagnosis was higher in the relapse group. Logistic regression analyses of relapse and remission groups revealed no significant separation of both groups using a combination of the parameters studied (data not shown).

Table 4 shows the differences in the expression of the genes of interest in patients with either the $\mathrm{B}$ cell or $\mathrm{T}$ cell immunophenotype. Our data show that CTGF (IGFBP-rP2) is specifically expressed in patients with the $B$ cell immunophenotype. ${ }^{26}$ Furthermore, significant differences between the B cell and T cell immunophenotype were found in IGF-II ( $72 \%$ in B cell $v 50 \%$ in T cell), IGFBP-2 (58\% in B cell $v$ $88 \%$ in $\mathrm{T}$ cell), and IGFBP-5 (13\% in B cell $v 44 \%$ in $\mathrm{T}$ cell) (table 4).

\section{DISCUSSION}

Advances in our knowledge of the IGF regulatory pathway have led to a better understanding of the regulation of proliferation and apoptosis. In many cell types, including haematopoietic cells and various tumours, ${ }^{27-29}$ the activation of the IGF-I receptor has been identified as a crucial step in the control of the cell cycle. ${ }^{30}$ At present, various alterations of the IGF signalling pathway have been described in malignant diseases, including leukaemia, namely: mutations of the type 1
IGF receptor ${ }^{31}$ and altered expression of IGF- $\mathrm{II}^{32}$ and of the M6P/IGF2R (type 2 IGF receptor) gene. ${ }^{33}$ In view of the transcriptional activation of IGFBP-3 by p53, mutations in T-ALL might be an additional link to altered function of the IGF regulatory system in malignant diseases. ${ }^{34}$

We chose to use the RT-PCR method because of the limited amount of bone marrow available. The proportion of leukaemic lymphoblasts in the samples at diagnosis varies between $40 \%$ and $99 \%$. Therefore false positive results in expression negative populations of malignant lymphoblasts cannot be excluded. Furthermore, no "real" control population for malignant lymphoblasts can be found. Lymphocytes from the mononuclear cell fraction in normal blood do not represent the precursor cell population and despite a high number of stem cells present in the mononuclear cells of cord blood they are not the non-malignant counterpart of malignant lymphoblasts.

Alterations of the IGF signalling pathway seen in patients with lymphoid neoplasia by far exceeded those seen in non-malignant conditions-for example, after protein restriction or growth hormone deficiency. ${ }^{35}$ In $57 \%$ of patients with ALL, a low serum concentration of total IGF-I was found. In addition, IGFBP-3 was reduced in one third of patients and western immunoblots of the corresponding serum samples showed increased proteolysis of IGFBP-3. ${ }^{21}$ Decreased formation or stability of the IGF-IGFBP-3-ALS complex as a result of increased IGFBP-3 proteolysis has been described previously in leukaemia and solid tumours, ${ }^{36}$ as well as in various catabolic stages ${ }^{37}$ and under anabolic conditions. ${ }^{38}$ Upregulation of IGFBP-2 gene transcription in mononuclear cells might be a possible source of raised serum IGFBP-2 values, and this hypothesis is in line with cell culture studies. ${ }^{39}{ }^{40}$ A strong inverse correlation between IGFBP-2 and free IGF-I and IGF-II has been described. ${ }^{41}$ These findings, together with an inverse correlation of IGFBP-2 with the ratio of free to total IGFs, suggest that IGFBP-2 is the major regulatory carrier of IGF in childhood leukaemia. ${ }^{41}$ Therefore, IGFBP-2 may act as an alternative carrier for IGFs when IGFBP-3 concentrations are low. ${ }^{42}$ In contrast, IGFBP-1 has been identified as a major component in the short term regulation of free IGF-I. ${ }^{43}$

Alterations in the IGF system have been reported to be predictive of outcome in solid tumours. High expression of IGFBP- $3^{44}$ and IGFBP- $4^{45}$ were correlated with poor outcome in breast cancer, whereas high IGF-I receptor content was a favourable prognostic indicator. ${ }^{46}$ In adrenocortical tumours increased IGF-II and IGFBP-2 values were associated with malignancy, ${ }^{47}$ and in meningioma a high ratio of IGF-II to IGFBP-2 mRNA was a marker of anaplasia. ${ }^{48}$ In addition, high serum IGFBP-2 concentrations were found in prostate cancer $^{49}$ and Wilms's tumour. ${ }^{50}$ In our patients, the occurrence of relapse was restricted to children with raised serum IGFBP-2 concentrations at diagnosis (data not shown). ${ }^{41}$ In these patients, intensified treatment might improve the rate of cure. Interestingly, a difference in IGFBP-2 expression in mononuclear cells at diagnosis was found between patients who were later continuously in remission (59\% expressed IGFBP-2) and patients who developed a haematological relapse (83\% expressed IGFBP-2). Using logistic regression analysis no combination of parameters was able to separate these two groups. In contrast, specific expression patterns could be used to separate patients with ALL from controls. In each analysis, more than five independent univariate parameters could be identified that together could distinguish the control group from the patients with ALL in a significant manner. This shows that the components of the IGF system are expressed differently in the mononuclear cells of these two groups and that the parameters studied act independently. The problem of the appropriate control population for leukaemic lymphoblasts has already been discussed. IGFBP-2 is the most important parameter in multivariate analysis to separate leukaemic lymphoblasts from normal cord blood mononuclear cells, followed by IGFBP-rP2 (CTGF), the type 2 IGF 


\section{Take home messages}

- Malignant lymphoblasts of patients with acute lymphoblastic leukaemia (ALL) express components of the insulin-like growth factor (IGF) system, thereby promoting their own growth in an autocrine, paracrine, or endocrine manner

- Patients who were in continuous remission had a lower percentage of IGF binding protein 2 (IGFBP-2) and IGFBP-3 expressing mononuclear cells at diagnosis than those who relapsed

- The prognostic usefulness of these factors in the stratification of ALL treatment in children needs to be evaluated

receptor, IGF-I, IGF-II, and the type I IGF receptor. Because undifferentiated cells are present in cord blood, the high percentage of IGFBP-2 expression in leukaemic transformed cells and its importance in the multivariate analysis seems to be pathognomonic of ALL. In contrast, IGF-II is an important fetal growth factor and it was expressed in a higher percentage of mononuclear cells in cord blood and leukaemic cells compared with age matched controls, probably because of high IGF-II expression in undifferentiated cells.

Although no significant difference could be found between the relapse and remission groups in the logistic regression analysis, IGFBP-2 and IGFBP-3 were significantly different in the $\chi^{2}$ test. This suggests that these factors in combination with other clinical parameters could be used to identify patients with a higher risk of relapse. Further evaluation of the IGF signalling pathway in acute lymphoblastic leukaemia may help to define those parameters and also open the way to new therapeutic approaches.

\section{ACKNOWLEDGEMENTS}

We thank all participating BFM study centres. This work was supported by Deutsche Leukämie Forschungshilfe (grants No. 95.01 and 97.03), Kultusministerium Sachsen/Anhalt (003VE1998), Magdeburger Förderkreis Krebskranker Kinder e.V., and the WA Drenckmann-Foundation.

\section{Authors' affiliations}

P Vorwerk, H Wex, B Hohmann, U Mittler, Department of Paediatric Oncology, Otto-von-Guericke-University Magdeburg,

Emanuel-Larisch-Weg 17-19, D-39112 Magdeburg, Germany

K Mohnike, Department of Paediatric Endocrinology,

Otto-von-Guericke-University Magdeburg

U Schmidt, Institute of Biometrics and Medical Informatics,

Otto-von-Guericke-University Magdeburg

\section{REFERENCES}

Engstrom W, Zetterberg A. Phosphate and the regulation of fibroblast cell proliferation. Biochem J 1983;214:695-702.

2 Schofield PN, Engstrom W. Insulin-like growth factors in human cancer In: Schofield PN, ed. The insulin-like growth factors. Structure and biological function. Oxford: Oxford University Press, 1992:241-57.

3 Spagnoli A, Rosenfeld RG. Insulinlike growth factor binding proteins. Current Opinion in Endocrinology and Diabetes 1997;4:1-9.

4 Zapf J, Schmid C, Froesch ER. Biological and immunological properties of insulin-like growth factors (IGF) I and II. Clin Endocrinol Metab $1984 ; 13: 3-30$

5 D'Ercole AJ, Stiles AD, Underwood LE. Tissue concentrations of somatomedin C: further evidence for multiple sites of synthesis and paracrine or autocrine mechanisms of action. Proc Natl Acad Sci U S A 1984:81:935-9.

6 Leof EB, Wharton W, van Wyk JJ, et al. Epidermal growth factor (EGF) and somatomedin $\mathrm{C}$ regulate $\mathrm{Gl}$ progression in competent BALB/C-3T3 cells. Exp Cell Res 1982;141:107-15.

7 Kiess W, Blickenstaff GD, Sklar MM, et al. Biochemical evidence that the type II insulin-like growth factor receptor is identical to the cation-independent mannose 6-phosphate receptor. J Biol Chem 1988;263:9339-44

$8 \mathrm{Kim}$ HS, Nagalla SR, Oh Y, et al. Identification of a family of low-affinity insulin-like growth factor binding proteins (IGFBPs): characterization of connective tissue growth factor as a member of the IGFBP superfamily. Proc Natl Acad Sci U S A 1997;94:12981-6.
9 Hwa V Oh Y, Rosenfeld RG. The insulin-like growth factor-binding protein (IGFBP) superfamily. Endocr Rev 1999;20:761-87.

10 Bradham DM, Igarashi A, Potter RL, et al. Connective tissue growth factor: a cysteine-rich mitogen secreted by human vascular endothelial cells is related to the SRC-induced immediate early gene product CEF-10. I Cell Biol 1991:114:1285-94.

11 Bork P. The modular architecture of a new family of growth regulators related to connective tissue growth factor. FEBS Lett 1993;327:125-30.

12 Oh Y, Nagalla SR, Yamanaka Y, et al. Synthesis and characterization of insulin-like growth factor-binding protein (IGFBP)-7. Recombinant human mac25 protein specifically binds IGF-I and -II. J Biol Chem 1996:271:30322-5

13 Oh Y, Muller HL, Pham H, et al. Demonstration of receptors for insulin-like growth factor binding protein-3 on $\mathrm{Hs} 578 \mathrm{~T}$ human breast cancer cells. J Biol Chem 1993;268:26045-8

14 Parker A, Clarke JB, Busby WH, et al. Identification of the extracellular matrix binding sites for insulin-like growth factor-binding protein 5. J Biol Chem 1996:271:13523-9.

15 Nishida T, Nakanishi T, Shimo T, et al. Demonstration of receptors specific for connective tissue growth factor on a human chondrocytic cell line (HCS-2/8). Biochem Biophys Res Commun 1998;247:905-9.

16 Collett-Solberg PF, Cohen P. The role of the insulin-like growth factor binding proteins and the IGFBP proteases in modulating IGF action. Endocrinol Metab Clin North Am 1996:25:591-614.

17 Holly JMP, Maile LA, Cwyfan Huges SC, et al. IGFBP proteasesphysiology/pathophysiology. In: Takano K, Hizuka N, Takahashi SI, eds. Molecular mechanisms to regulate the activities of insulin-like growth factors. Amsterdam: Elsevier, 1998:89-97.

18 Vorwerk P, Yamanaka Y, Spagnoli A, et al. Insulin and IGF binding by IGFBP-3 fragments derived from proteolysis, baculovirus expression and normal human urine. J Clin Endocrinol Metab 1998;83:1392-5.

19 Yamanaka Y, Wilson EM, Rosenfeld RG, et al. Inhibition of insulin receptor activation by insulin-like growth factor binding proteins. J Biol Chem 1997;272:30729-34.

20 Lalou C, Lassarre C, Binoux M. A proteolytic fragment of insulin-like growth factor (IGF) binding protein-3 that fails to bind IGFs inhibits the mitogenic effects of IGF-I and insulin. Endocrinology 1996;137:320612 .

21 Mohnike KL, Kluba U, Mittler U, et al. Serum levels of insulin-like growth factor-l, -II and insulin-like growth factor binding proteins -2 and -3 in children with acute lymphoblastic leukaemia. Eur J Pediatr 1996:155:81-6.

22 Flyvbjerg A, Mogensen O, Mogensen B, et al. Elevated serum insulin-like growth factor-binding protein 2 (IGFBP-2) and decreased IGFBP-3 in epithelial ovarian cancer: correlation with cancer antigen 125 and tumor-associated trypsin inhibitor. J Clin Endocrinol Metab 1997:82:2308-13.

23 Ho PJ, Baxter RC. Insulin-like growth factor-binding protein-2 in patients with prostate carcinoma and benign prostatic hyperplasia. Clin Endocrinol (Oxf) 1997;46:333-42.

24 Toropainen EM, Lipponen PK, Syrianen KJ. Expression of insulin-like growth factor II in female breast cancer as related to established prognostic factors and long-term prognosis. Anticancer Res 1995;15:2669-74.

25 Wex H, Vorwerk P, Mohnike K, et al. Elevated serum levels of IGFBP-2 found in children suffering from acute leukaemia is accompanied by the occurrence of IGFBP-2 mRNA in the tumour clone. Br J Cancer 1998;78:515-20

26 Vorwerk P, Wex H, Hohmann B, et al. CTGF (IGFBP-rP2) is specifically expressed in malignant lymphoblasts of patients with acute lymphoblastic leukaemia (ALL). Br J Cancer 2000;83:756-60.

27 Steller MA, Delgado CH, Zou Z. Insulin-like growth factor II mediates epidermal growth factor-induced mitogenesis in cervical cancer cells. Proc Natl Acad Sci U S A 1995:92:11970-4.

28 Cullen KJ, Yee D, Rosen N. Insulinlike growth factors in human malignancy. Cancer Invest 1991;9:443-54

29 Cianfarani S, Rossi P. Neuroblastoma and insulin-like growth factor system. New insights and clinical perspectives. Eur J Pediatr 1997; 156:256-61

30 Reiss K, Porcu P, Sell C, et al. The insulin-like growth factor 1 receptor is required for the proliferation of hemopoietic cells. Oncogene 1992; 7:2243-8

31 Kellerer M, Obermaier-Kusser B, Ermel B, et al. An altered IGF-I recepto is present in human leukemic cells. J Biol Chem 1990;265:9340-5.

32 Dong G, Rajah R, Vu T, et al. Decreased expression of Wilms' tumor gene WT-1 and elevated expression of insulin growth factor-II (IGF-II) and type 1 IGF receptor genes in prostatic stromal cells from patients with benign prostatic hyperplasia. J Clin Endocrinol Metab 1997;82:2198-203.

33 De Souza AT, Hankins GR, Washington MK, et al. M6P/IGF2R gene is mutated in human hepatocellular carcinomas with loss of heterozygosity. Nat Genet 1995:11:447-9.

34 Buckbinder L, Talbott R, Velasco-Miguel S, et al. Induction of the growth inhibitor IGF-binding protein 3 by p53. Nature 1995;377:646-9.

35 Smith WJ, Underwood LE, Clemmons DR. Effects of caloric or protein restriction on insulin-like growth factor-I (IGF-I) and IGF-binding proteins in children and adults. J Clin Endocrinol Metab 1995;80:443-9.

36 Muller HL, Oh Y, Gargosky SE, et al. Insulin-like growth factor binding protein-3 concentrations and insulin-like growth factor binding protein-3 protease activity in sera of patients with malignant solid tumors or leukemia. Pediatr Res 1994;35:720-4.

37 Davies SC, Wass JA, Ross RJ, et al. The induction of a specific protease for insulin-like growth factor binding protein-3 in the circulation during severe illness. J Endocrinol 1991;130:469-73. 
38 Lassarre C. Tauber MT, Rochiccioli $P$, et al. Circadian variations in plasma IGFBP-3 proteolysis. Horm Res 1996;46;34

39 Nyman T, Pekonen F. The expression of insulin-like growth factors and their binding proteins in normal human lymphocytes. Acta Endocrinol 1993; 128: 168-72.

40 Neely EK, Smith SD, Rosenfeld RG. Human leukemic T and B lymphoblasts produce insulin-like growth factor binding proteins 2 and 4. Acta Endocrinol (Copenh) 1991; 124:707-14.

41 Mohnike K, Kluba U, Aumann V, et al. IGFBP-2 at diagnosis of lymphoid neoplasia predicts relapse risk [abstract]. Growth Horm IGF Res 2000:10:A38

42 Bang $\mathbf{P}$, Westgren M, Schwander J, et al. Ontogeny of insulin-like growth factor-binding protein-1, -2, and -3: quantitative measurements by radioimmunoassay in human fetal serum. Pediatr Res 1994;36:528-36.

43 Frystyk J, Hussain M, Skjaerbaek C, et al. Serum free IGF-I during a hyperinsulinemic clamp following 3 days of administration of IGF-I vs. saline. Am J Physiol 1997;273:E507-13.

44 Rocha RL, Hilsenbeck SG, Jackson JG, et al. Correlation of insulin-like growth factor-binding protein-3 messenger RNA with protein expression in primary breast cancer tissues: detection of higher levels in tumors with poor prognostic features. J Natl Cancer Inst 1996;88:601-6.
45 Yee D, Sharma J, Hilsenbeck SG. Prognostic significance of insulin-like growth factor-binding protein expression in axillary lymph node-negative breast cancer. J Natl Cancer Inst 1994;86:1785-9.

46 Papa V, Gliozzo B, Clark GM, et al. Insulin-like growth factor-l receptors are overexpressed and predict a low risk in human breast cancer. Cancer Res 1993;53:3736-40.

47 Boulle N, Logie A, Gicquel C, et al. Increased levels of insulin-like growth factor II (IGF-II) and IGF-binding protein-2 are associated with malignancy in sporadic adrenocortical tumors. J Clin Endocrinol Metab 1998:83:1713-20.

48 Nordqvist AC, Peyrard M, Pettersson $\mathrm{H}$, et al. A high ratio of insulin-like growth factor II/insulin-like growth factor binding protein 2 messenger RNA as a marker for anaplasia in meningiomas. Cancer Res 1997;57:2611-14

49 Kanety H, Madjar Y, Dagan Y, et al. Serum insulin-like growth factor-binding protein-2 (IGFBP-2) is increased and IGFBP-3 is decreased in patients with prostate cancer: correlation with serum prostate-specific antigen. J Clin Endocrinol Metab 1993;77:229-33.

50 Zumkeller W, Schwander J, Mitchell CD, et al. Insulin-like growth factor (IGF)-I, -II and IGF binding protein-2 (IGFBP-2) in the plasma of children with Wilms' tumour. Eur J Cancer 1993;29A: 1973-7.

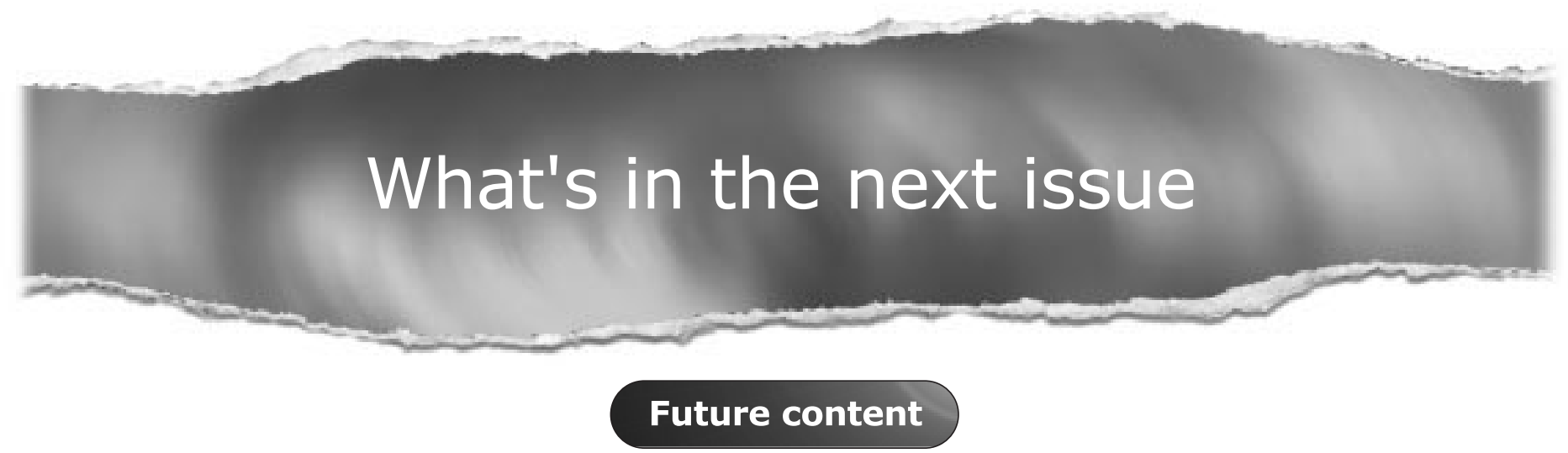

See which articles have just been accepted for publication and preview the table of contents for the next issue a month before it is published

www.jclinpath.com 